\title{
Financial performance of Bandar Lampung City Government (Comparing the accountability of two mayor periods: 2006 - 2010 vs 2011 - 2015)
}

\section{Ferry Aryadi $^{1 *}$, Ayi Ahadiat ${ }^{2}$, Ribhan $^{3}$}

Faculty Economics and Business, University of Lampung ${ }^{1,2,3}$ aryadi.ferry@gmail.com ${ }^{1}$, ayi.ahadiat2017@gmail.com ${ }^{2}$, ribhan@feb.unila.ac.id ${ }^{3}$

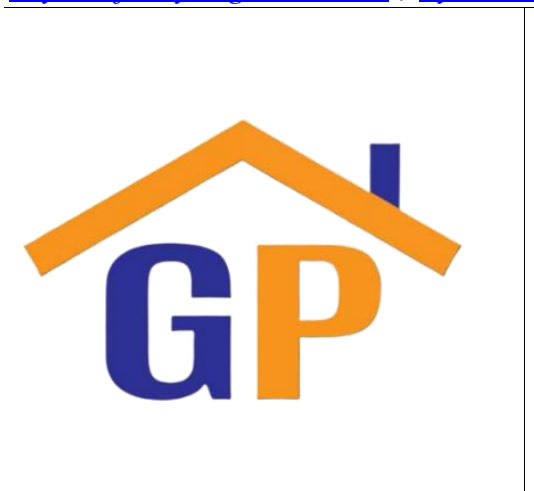

Article History

Received on 1 September 2020

$1^{\text {st }}$ Revision on 26 September 2020

$2^{\text {nd }}$ Revision on 6 October 2020

Accepted on 8 October 2020

\section{Abstract}

Purpose: The purpose of this research was to determine the significance of differences in financial performance, community welfare, and Gross Regional Domestic Product (GDP) of Bandar Lampung City in two mayor periods.

Research Methodology: This study used secondary data obtained directly from the Lampung Provincial Representative Audit Board with a complete-time series of 10 years during the period $2006-$ 2015. The research used region government financial performance, society welfare as measured by the human development index, Gross Regional Domestic Product (GDP) Based on Constant Prices as the variable. By one way-ANOVA to analyze technical data on this research.

Results: There is no significant difference in the average financial performance in the form of effectiveness ratios, efficiency ratios, expenditure balance ratios, and government financial growth ratios of Bandar Lampung in two major periods. However, this research finds there is a significant difference in the average of social welfare as measured by the Human Development Index (HDI) and Gross Regional Domestic Product (GDP) of Bandar Lampung city in two major periods. This means that the Bandar Lampung City Government has not been able to properly maintain and increase its growth.

Limitations: This research took a sample in this study only Bandar Lampung city, while in Lampung province there are 15 regencies/cities, and this research in conducting disparate tests using the Anova test. This research would be better if using more samples and using another test.

Contribution: This study contributes to providing input and advice to the city government in making decisions related to the preparation and realization of the Regional Revenue and Expenditure Budget in the future.

Keywords: Financial performance, Effectiveness, Efficiency, A harmony of spending, Financial growth

How to cite: Aryadi, F., Ahadiat, A., Ribhan. (2020) Financial performance of Bandar Lampung City Government (Comparing the accountability of two mayor periods: $2006-2010$ vs $2011-2015$ ). International Journal of Financial, Accounting, and Management, 2(3), 213-225. 


\section{Introduction}

Oates, (1993) states that people's welfare can be quickly realized by implementing fiscal decentralization and its implementation in the regions is the responsibility of the government in the regions. Fiscal decentralization is expected to be able to increase economic growth and social welfare because local governments will be more efficient in the production and supply of public goods. This statement is supported by Rahmawati \& Mahmudi, (2016), who states that in the context of implementing regional autonomy and fiscal decentralization, local governments are required to have greater regional financial independence. Therefore, attention to revenue management and analysis of regional revenues (regional financial performance) is very important for local governments. For example, such as the city of Bandar Lampung is the capital of Lampung province.

The city of Bandar Lampung can be a measure of the success of regional financial management to improve community welfare and economic success. The city government of Bandar Lampung has always been highly committed to continuously improving the welfare of the people in the region. To improve the welfare of the community, it can be seen only from the amount of public expenditure budget allocated for public facilities and services to the community towards the total regional budget from the Regional Revenue and Expenditure Budget Report and Budget Realization Report. Financial performance analysis in the Regional Revenue and Expenditure Budget Report (audited) is carried out by comparing the results achieved from one period with the previous period so that trends can be seen. Besides that, it can also be done by analyzing financial ratios in the form of effectiveness ratios, efficiency ratios, expenditure compatibility ratios, and financial growth ratios (Rahmawati \& Mahmudi, 2016). Good regional financial management will be shown by good financial performance (Sularso \& Restianto 2012).

Bandar Lampung City Government in the Fiscal Year (FY) 2006 to 2015 has realized the Regional Revenue and Expenditure Budget Report in terms of expenditure which is expected to increase public services. The realization of direct and indirect expenditure of the Bandar Lampung City government from 2006 to 2015 FY can be seen in the following Table 1.

Table 1. Realization of the Direct and Indirect Expenditures of Bandar Lampung City Fiscal Year $2006-2015$

\begin{tabular}{|c|c|c|c|c|c|}
\hline Years & $\begin{array}{c}\text { Direct Expenditures } \\
\text { (IDR) }\end{array}$ & $\begin{array}{c}\text { Indirect Expenditures } \\
\text { (IDR) }\end{array}$ & \multirow{2}{*}{$\begin{array}{c}\text { Total } \\
\text { (IDR) }\end{array}$} & & \multicolumn{2}{|c|}{$\begin{array}{c}\text { Direct } \\
\text { Expenditures }\end{array}$} & $\begin{array}{c}\text { Indirect } \\
\text { Expenditures }\end{array}$ \\
\hline 2006 & $65,757,761,765.63$ & $499,230,830,882.00$ & $564,988,592,647.63$ & $11.64 \%$ & $88.36 \%$ \\
\hline 2007 & $278,414,536,115.00$ & $374,542,246,490.13$ & $652,956,782,605.13$ & $42.64 \%$ & $57.36 \%$ \\
\hline 2008 & $316,059,385,868.00$ & $462,718,128,184.53$ & $778,777,514,052.53$ & $40.58 \%$ & $59.42 \%$ \\
\hline 2009 & $302,667,431,385.00$ & $499,428,199,977.29$ & $802,095,631,362.29$ & $37.73 \%$ & $62.26 \%$ \\
\hline 2010 & $278,758,117,709.00$ & $649,412,523,772.58$ & $928,170,641,481.58$ & $30.03 \%$ & $69.98 \%$ \\
\hline 2011 & $399,266,378,195.40$ & $755,362,215,539.44$ & $1,154,628,593,734.84$ & $34.58 \%$ & $65.42 \%$ \\
\hline 2012 & $657,523,994,710.96$ & $807,464,932,172.92$ & $1,464,988,926,883.88$ & $44.88 \%$ & $55.12 \%$ \\
\hline 2013 & $844,990,112,937.84$ & $934,869,752,330.01$ & $1,779,859,865,267.85$ & $47.47 \%$ & $52.52 \%$ \\
\hline 2014 & $854,625,165,231.08$ & $944,850,740,184.20$ & $1,799,475,905,415.28$ & $47.49 \%$ & $52.51 \%$ \\
\hline 2015 & $738,129,793,503.34$ & $1,019,290,069,731.94$ & $1,757,419,863,235.28$ & $42.00 \%$ & $58.00 \%$ \\
\hline
\end{tabular}

Source: Regional Government Financial Reports Bandar Lampung City, FY 2006 to 2015 (processed) 
Based on the data in Table 1, it is known that the Government of the City of Bandar Lampung has realized fluctuating direct expenditure/public services from the total of Regional Revenue and Expenditure Budget Report available from FY 2006 to 2015. Based on Table 1 in the proportion column, it is known that the portion of direct expenditure is lower compared to the indirect shopping portion. The part of direct expenditure initially increased but returned to a declining trend until the 2010 fiscal year which then increased again to the highest composition that occurred in the 2013 and 2014 fiscal years of $47.48 \%$ and $47.49 \%$ compared to indirect expenditure. Apart from those seen in Table 1, the performance of local governments can be analyzed using financial ratios to the Regional Revenue and Expenditure Budget Report that are determined and implemented (Abdul \& Syam 2012; Halim \& Kusufi 2012, 2014a; Halim 2017). Several financial ratios can be used to measure local government accountability (Abdullah, 2017; and Halim, 2017) namely the ratio of effectiveness to local own-source revenue, the ratio of efficiency of regional expenditure, the ratio of expenditure harmony, and the ratio of financial growth. The following is a financial ratio table to measure the accountability of the Bandar Lampung City Government for the period 2006 to 2015.

Table 2. Financial Ratios for Measuring the Accountability of the Bandar Lampung Municipal Government for the Year 2006 - 2015

\begin{tabular}{|c|c|c|c|c|c|}
\hline Years & $\begin{array}{c}\text { Effectiveness } \\
\text { Ratio PAD }\end{array}$ & $\begin{array}{c}\text { Efficiency } \\
\text { Ratio of } \\
\text { Expenditures }\end{array}$ & $\begin{array}{c}\text { Public } \\
\text { Spending } \\
\text { Ratio }\end{array}$ & $\begin{array}{c}\text { Apparatus } \\
\text { Expenditures } \\
\text { Ratio }\end{array}$ & Growth Ratio \\
\hline 2006 & $97.14 \%$ & $93.43 \%$ & $82.56 \%$ & $10.87 \%$ & $44.53 \%$ \\
\hline 2007 & $98.33 \%$ & $94.10 \%$ & $39.69 \%$ & $53.39 \%$ & $11.93 \%$ \\
\hline 2008 & $111.98 \%$ & $99.69 \%$ & $40.46 \%$ & $59.23 \%$ & $12.31 \%$ \\
\hline 2009 & $97.81 \%$ & $94.54 \%$ & $35.67 \%$ & $58.86 \%$ & $6.08 \%$ \\
\hline 2010 & $103.00 \%$ & $96.81 \%$ & $29.11 \%$ & $67.82 \%$ & $20.87 \%$ \\
\hline 2011 & $103.84 \%$ & $97.37 \%$ & $33.72 \%$ & $63.79 \%$ & $23.86 \%$ \\
\hline 2012 & $102.20 \%$ & $96.08 \%$ & $43.15 \%$ & $52.99 \%$ & $22.86 \%$ \\
\hline 2013 & $86.27 \%$ & $94.48 \%$ & $44.87 \%$ & $49.64 \%$ & $15.69 \%$ \\
\hline 2014 & $79.69 \%$ & $91.62 \%$ & $43.53 \%$ & $48.13 \%$ & $8.74 \%$ \\
\hline 2015 & $51.69 \%$ & $77.22 \%$ & $32.43 \%$ & $44.79 \%$ & $0.41 \%$ \\
\hline
\end{tabular}

Source: Regional Government Financial Reports Bandar Lampung City, FY 2006 to 2015 (processed)

Based on Table 2 it can be seen that in general the financial ratios for measuring the accountability of the Bandar Lampung regional government, in general, have fluctuated from year to year. Table 2 shows that the financial ratio showed a downward trend from 2006 to 2015. The amount of direct expenditure, indirect expenditure, and financial performance is expected to have a significant impact on economic growth. Economic growth can be measured by human development which can be seen by the level of quality of human life. One of the benchmarks used in seeing the quality of human life is the HDI which is measured by health and life expectancy, education, and living standards. Through the improvement of these indicators, it is hoped that there will be an increase in the quality of human life. The Mayor of Bandar Lampung as the regional leader plays a very strategic role in managing and advancing the City of Bandar Lampung. Strategic planning is vital because there will be seen the role of regional heads in coordinating all work units. From 2005 to 2015, the City of Bandar Lampung has experienced a change of Mayor of Bandar Lampung, which is also accompanied by changes in systems and procedures for administration and accounting, reporting, and regional financial accountability.

Research on regional financial performance in Indonesia has been carried out, many of which are intended to evaluate the financial performance of local governments. This shows the tendency of high attention to improving the quality of performance of government agencies, especially in providing services to the community. Among the research conducted by (Batafor, 2011) that is related to the evaluation of the financial performance of the Government of Lembata Regency, East Nusa Tenggara, the results show that financial performance is not significantly different in the level of independence and effectiveness ratios with the calculation results there is an increase, but the results of the calculation 
of the ratio of efficiency and harmony of spending decreased in a period I compared period II. Subsequent research was conducted by (Nirwana, Taufik, \& Ratnawati 2014) who researched evaluating the financial performance of the Bengkalis Regency Government over 2 periods of regional head leadership. The results showed that there were significant differences in the ratio of independence and the ratio of the effectiveness of local original income Period I and II, while the ratio of expenditure, the harmony of apparatus expenditure, and the ratio of balance in public service spending in Period I and II concluded there was no significant difference.

This research is a replication, which is a case study that evaluates the financial performance of local governments in the city of Bandar Lampung. This research period refers to two periods of regional head administration, namely period I led by Eddy Sutrisno or ES and period II period led by Herman Hasan Nusin (HHN). This is to see the seriousness of the regional government to improve financial performance with a variety of policies that have been implemented during the two periods of government. In this study, the period in effect is the period I from 2006-2010 and the second period from 2011-2015. This study aims to determine the comparative financial performance of the Bandar Lampung City Government in 2006 - 2015, namely by comparing the two major periods.

\section{Literature review and hypotheses development}

According to Zafra-Gómez et al. (2009), there are several ways for assessing local government financial conditions, but assets and liabilities are to be taken into account to assess sustainability, flexibility, and vulnerability. Mogues \& Benin (2012) found out that external grants discourage local government efforts to raise revenue locally. Another way of assessing government financial performance relates to the fiscal health of the city in terms of the risk of bankruptcy, which according to Whitney (2013) is the result of "budgetary mismanagement coupled with rising pension and debt costs". In the United States, several cases of cities have declared bankruptcy to have "the time and fiscal breathing room required to develop and negotiate plans for reorganizing debt while protecting the government from its creditors". The concept of welfare economics is concerned with maximizing the welfare of individuals and society through optimal allocation of resources. The concept of welfare economics is characterized primarily by a great concern for equality between individuals in society. According to Karimah et al., (2020), to analysis of the influence of regional government financial performance which is proxied by the independence of regional finances, the effectiveness of regional finances, the growth of regional income, and the harmony of regional spending on the level of welfare of society, it can be concluded that only the regional independence variable has a significant effect on the level of welfare of society.

According to Pigou, (2013), welfare economic theory is a part of social welfare that can be linked directly or indirectly to the measurement of money. Economic development carried out by the welfare state must correlate with the benefit and prosperity of the people. Two things are directly related to economic development efforts: First, the realization of a welfare state is not separate from the efforts of economic development. As has been stated, economic development must make society more prosperous, not the other way around. Second, the goal of the welfare state is not only for reasons of equality but also for efficiency in the economic process. The main key in the welfare state is the issue of guaranteeing the welfare of the people by the state (Barr, 2020).

Based on Suharto, (2005), the term social welfare is often defined as a condition of well-being (the first conception), which is a condition where all forms of life need are met, especially those that are basic such as food, clothing, housing, education, and health care. Suharto (2005) and United Nations Development Program (2010) revealed that social welfare, economic growth (finance, industry), society care (health, social welfare), human development (education), can be seen from various indicators. In Indonesia, the indicators used to measure the general achievement of the level of community welfare in an area carried out by the Central Statistics Agency are using the HDI with three indicators, namely health/longevity (measured by life expectancy), knowledge (measured by educational attainment), and eligibility (measured by adjusted income).

According to Boberg-Fazlic \& Sharp, (2013) in a survey of economic and social welfare indicators, economic and social welfare can be measured through the Genuine Progress Indicator (GPI), Measure of Economic Welfare (MEW), index of economic well-being (IEWB), Index of Social Health. (ISH), 
and Index of Living Standards (ILS). Where every measure of welfare indicators MEW, GPI, and IEWB emphasize economic indicators compared to other indicators, while ISH and ILS refer more to social variables. Thus the welfare context in this study focuses more on the dimensions of material living standards that will be represented by GDP as well as the dimensions forming the HDI figure for each region such as the dimensions of decent living standards in the form of adjusted per capita expenditure, the health dimension represented by life expectancy at birth and the education dimension. / knowledge represented by literacy rate expected length of schooling and an average length of schooling.

As quoted from UNDP (United Nation Development People) (2010), human development is a process of increasing choices and enhancing human capabilities (a process of enlarging people's choices). A process that pays attention to the creation of a supportive environment where humans can develop their potential and play a full productive role and live concerning their needs and interests. One of the benchmarks used in looked at the quality of human life is the Human Development Index (HDI) which is measured through health and life expectancy, education, and living standards (https://quickonomics.com, 2019). To see the HDI achievements between regions, it can be seen through the grouping of HDI into several categories, which are shown in Table 3. below:

Table 3. Criteria for Human Development Index (HDI)

\begin{tabular}{cc}
\hline Human Development Index (HDI) & Criteria \\
\hline$<60$ & Low \\
$60 \leq \mathrm{HDI}<70$ & Medium \\
$70 \leq \mathrm{HDI}<80$ & High \\
HDI $\geq 80$ & Very High \\
\hline Source: https://ipm.bps.go.id/page/ipm, 2019
\end{tabular}

Economic growth is one indicator of the success of development in an economy. The welfare and progress of an economy are determined by the amount of growth indicated by changes in national output. The change in output in the economy is a short-term economic analysis. The government needs a budget to carry out its functions properly and the mechanism for implementing this budget is carried out through fiscal policy. The fiscal policy reflects the size, growth, and structure of the government budget adopted by a country (Ma'ruf \& Wihastuti, 2008). Economic growth is one important indicator in analyzing the performance of economic development occurring in a region/country (Kuncoro, 2004). Economic growth shows the extent to which economic activity would generate additional income in a given period. Mankiw, (2014) states that economic growth shows the extent to which economic activity would generate additional income in a given period. Because the economy is a process of using the factors of production to produce output, then this process will in turn generate a stream of remuneration to the factors of production that are owned by society. Government expenditure that has a positive influence on economic growth is related to government performance. One of the tools to analyze government performance is to analyze financial performance. One of the tools for analyzing the performance of local governments is to analyze the financial ratios against the established and implemented Regional Revenue and Expenditure Budget Report (Halim, 2017).

Government Regulation of the Republic of Indonesia Number 20 of 2004 concerning Government Work Plans states that the performance report becomes input and material for consideration for the analysis and evaluation of the next year's budget proposals submitted by the relevant state ministries/agencies. Several financial ratios that can be used to measure the accountability of local government (Halim, 2017), namely the ratio of effectiveness to local revenue, efficiency ratio of regional expenditures, expenditure balance ratio, and financial growth ratio.

Agency theory states that an agency relationship is a contract whereby one or more (principals) delegate authority to another person (agent) for their interests. This agency relationship problem results in asymmetric information and conflicts of interest (Jensen \& Meckling, 1976, 1979a, 1979b). Furthermore, Sochib (2016) explains that an agency relationship is a contract that consists of one or more parties called the principals, who employ a party, which is the agent, accomplish several services, and afterward delegates decision-making authority to the agent. Agency theory seeks to describe the 
relationship between agents and principals by using the mechanism of a contract. Agency theory uses the emphasis on solving two problems:

1) Agency problems that arise when the desires/goals between agents and principals conflict, and it is difficult for principals to verify the real work of agents.

2) Risk-sharing problems that occur when principals and agents have different preferences and attitudes towards risk.

The focus of agency theory Eisenhardt, (1989); and Bjurstrøm, (2020) is the determination of the contract that most efficiently regulates the relationship between the principal and the agent assuming that:

1) Humans have selfish interests, bounded rationality, risk aversion;

2) The organization includes conflicts of interest between its members, and

3) Information is a commodity and can be purchased.

The linkage of agency theory in this study can be seen through the relationship between the community and the local government. The relationship between the community and the government is like the relationship between the principal and agent. The people represented by the Regional People's Representative Assembly are the principal and the government is the agent. The agent is expected to take advantage of the principal's financial policies. The principal has the authority to regulate the agent, and provide resources to the agent in the form of taxes, levies, balancing funds, the results of the management of regional assets, and other legitimate regional income. The regional government as the party entrusted with the task of carrying out the management of government, development, and community service, must submit a report on its financial accountability to assess whether the regional government is successfully carrying out its duties properly or not. If the agent's decision is detrimental to the principal, agency problems will arise. Because they do not know what the agent does (asymmetric information), the principal needs a third party who can convince the principal that what the agent reported is true.

Performance in organizations is the answer to the success or failure of organizational goals that have been set. cost, performance can also be interpreted as a description of the level of achievement of the implementation of a program/policy activity in realizing the goals, objectives, mission, and vision of the organization as set out in an organization's strategic plan. Financial performance an carried out to assess past performance by conducting various to obtain a financial position that represents the reality of the entity and the potential for continued performance. If the achievement is following the plan, it can be said that the performance has been good. Or if the achievement exceeds what is planned then the performance is very good, on the contrary, if the achievement is not following what has been planned means that the performance that has been done is bad (Sularso \& Restianto, 2012).

One of the tools to analyze the performance of regional governments is by analyzing financial ratios against the Regional Revenue and Expenditure Budget Report that are determined and implemented (Halim, 2017). Government Regulation of the Republic of Indonesia Number 20 of 2004 concerning Government Work Plans states that performance reports become input and consideration for the analysis and evaluation of next year's budget proposals submitted by the relevant state ministries/agencies. Some financial ratios that can be used to measure local government accountability are the ratio of effectiveness to local own-source revenue, the ratio of regional expenditure efficiency, the ratio of expenditure harmony, and the ratio of financial growth (Abdul \& Syam, 2012; Halim \& Kusufi, 2012a, 2012b, 2014b, 2014a; Halim, 2017).

Good regional financial management will be demonstrated by good financial performance (Sularso \& Restianto, 2012). Meanwhile, one tool to analyze the performance of local governments in managing their regional finances is by analyzing the financial ratios that have been set and implemented (Halim. 2017). In the framework of the regional financial management of Bandar Lampung City for the welfare of the community, financial management must be more transparent, trustworthy, democratic, effective, efficient, and accountable. Regional leaders play a very strategic role in managing and advancing the areas they lead. Strategic planning is vital because there will be seen the role of the Regional Head in coordinating all work units so that the results are optimal. The systems and procedures for 
administration and accounting, reporting, and accountability of regional finances from 2006 to 2016 underwent several changes. Changes in the system and administration procedures are contained in Minister of Home Affairs Regulation Number 13 of 2006 as amended to Minister of Home Affairs Regulation Number 21 of 2011. So that with the change of mayors and changes in Minister of Home Affairs Regulation are expected to bring changes in financial performance better.

Batafor, (2011) revealed that financial performance was not significantly different in the level of independence ratio and effectiveness ratio with the results of the calculation there was an increase, but the results of the calculation of the ratio of efficiency and harmony of spending decreased in a period I compared to period II in Lembata District, East Nusa Tenggara Province. Nirwana et al., (2014) shows that there is a significant difference in the ratio of independence as well as the ratio of the effectiveness of regional original income Period I and II in the Bengkalis Regency Government. As for the expenditure ratio, the appropriateness ratio of apparatus spending and the harmony ratio of public service expenditure in Period I and II concluded that there were no significant differences in the Bengkalis Regency Government.

\section{$\mathrm{H}_{1}$ : There is a significant difference in the average financial performance of the Bandar Lampung City government in the period I and period II, namely the leadership period of ES and HHN.}

\section{Research methodology}

The data used are secondary, namely time series data on the financial performance of the Bandar Lampung City government from 2006-2015. The ratio of financial effectiveness of the Bandar Lampung City Government is measured by comparing the revenue realization with the revenue budget, in percent units. Rahmawati \& Mahmudi, (2016) states that simply the effectiveness ratio can be formulated as follows:

$$
\text { Effectiveness Ratio locally }- \text { generated revenue }=\frac{\text { realization of Locally }- \text { generated revenue }}{\text { Locally }- \text { generated revenue acceptance target }}
$$

The ratio of financial efficiency of the Bandar Lampung City government is measured by comparing the realization of expenditure with a predetermined budget, in units of percent. According to Mahmudi, (2007); Rahmawati \& Mahmudi, (2016) states that the efficiency ratio is measured by formulating it as follows:

$$
\text { Efficiency Ratio of Expenditures }=\frac{\text { Realization of expenditure }}{\text { Predetermined budget }}
$$

Indirect Expenditures ratio:

Appropriateness Ratio for Apparatus/Indirect Expenditures is measured by comparing the realization of total public expenditure with total regional expenditure in units of percent. According to Utama, (2015) the apparatus / indirect expenditure harmony ratio is measured using the formula:

$$
\text { Indirect Expenditures }=\frac{\text { Realization of total public expenditure }}{\text { Total regional expenditure }}
$$

Public Service Expense / Direct Expenditures Ratio

The ratio of the harmony of public service expenditure/direct expenditure is measured by comparing the realization of public expenditure with the regional budget in percent. According to Utama, (2015) The ratio of expenditure for public service apparatus / direct expenditure is measured using the formula:

$$
\text { Direct Expenditures Ratio }=\frac{\text { Realization of public expenditure }}{\text { Regional budget }}
$$


Growth ratio is measured by comparing $\mathrm{t}$ year income with $\mathrm{t}$ year income $\mathrm{t}-1$. According to Mahmudi, (2007); and Rahmawati \& Mahmudi, (2016)), the formula for calculating Growth Ratio is as follows:

$$
\mathrm{r}=\frac{\mathrm{t} \text { year income }- \text { year income } \mathrm{t}-1}{\text { year income } \mathrm{t}-1}
$$

One-Way ANOVA Analysis

Hypothesis testing is done with a statistical test tool that is the analysis of variance. According to Purnomo, (2016); and Wahyudi, (2017), analysis of variance is an average hypothesis test of more than two populations. The analysis of variance used in this study is One-Way ANOVA. One-Way ANOVA commonly known as one-factor completely randomized design of Anova is a hypothetical test of the average difference of more than two populations if each member involved in the measurement is free to be located in any population, meaning there is no gap to set the location a member in a particular population (so-called completely randomized). Arifin, (2017); and Pramesti \& Si, (2015) states that the One Way Anova test is a type of parametric statistical test that aims to determine whether there is an average difference between more than two sample groups. What is meant by one direction is that the source of diversity analyzed only goes one way, namely between groups.

Ho: $\mu 1=\mu 2=\mu 3 \ldots=\mu \mathrm{k}$ (the average of all groups is the same)

Ha: $\mu 1 \neq \mu 2 \neq \mu 3$ (there are averages of two or more unequal groups)

Following are the one-way Anova test assumptions:

a. Each data period is randomly chosen.

b. Clusters of each data period are normally distributed.

\section{Results and discussions}

This study uses the One Way Anova test which is available in SPSS 25.00 for Windows software, comparing financial performance variables, Human Development Index, and Gross Regional Domestic Product in the period I and period II in the Bandar Lampung City Government environment. The significance value used at $(\alpha)$ is $5 \%$ or a confidence level of $95 \%$, using a 2 -way test, so $\alpha / 2$ is $5 \% / 2=0.025$. The value of the $\mathrm{F}$ table is obtained by determining the numerator DK and the denominator DK. DK numerator $=$ sample group -1 , DK denominator $=$ number of sample - sample group. Where in this study using 2 sample groups, namely period I and period II with a total sample of 10 , so the numerator $\mathrm{DK}=2-1=2$, and the denominator DK $=10-2=8$, with a 2 -way test that is $\alpha$ of 0.025 obtained the value of $F$ table is 7,571. The stages of hypothesis testing are carried out as follows:

1. The difference in Financial Performance in the form of effectiveness ratio, efficiency ratio, the ratio of expenditure harmony, and the ratio of financial growth of the City Government of Bandar Lampung in the period I and period II

2. The One Way Anova test results on the differences in the financial performance of the Bandar Lampung City Government in the period I and period II are shown in the following Table 4:

Table 4. One Way Anova Test Results in Differences in Financial Performance of the Bandar Lampung City Government in Period I and Period II

\begin{tabular}{llll}
\hline Variable & $\mathrm{S}_{\text {tatistics }}$ & $\mathrm{F}_{\text {table }}$ & Sig. \\
\hline $\begin{array}{l}\text { Effectiveness Ratio Locally- } \\
\text { generated revenue }\end{array}$ & 0.012 & 7.571 & $0.915>0.025$ \\
$\begin{array}{l}\text { Efficiency Ratio of Expenditures } \\
\text { Public Spending Ratio }\end{array}$ & 0.173 & 7.571 & $0.689>0.025$ \\
Apparatus Expenditures Ratio & 0.030 & 7.571 & $0.867>0.025$ \\
Growth Ratio & 1.858 & 7.571 & $0.210>0.025$ \\
\hline
\end{tabular}

Source: data processed, 2019

Based on Table 4, it can be seen the significance value for the Locally-generated revenue Effectiveness Ratio of 0.915, Efficiency Ratio of 0.689, Appropriateness / Apparatus Spending Ratio of 0.867, Public Service Expenditures / Direct Spending Ratio of 0.210, and Financial Growth Ratio of 0.514. Based on 
the results of the study it can be seen that all significance values are greater than $>$ significance value

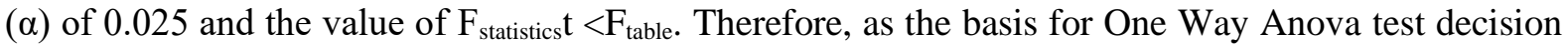
making, it can be concluded that the alternative hypothesis $\left(\mathrm{H}_{1}\right)$ is rejected and $\left(\mathrm{H}_{0}\right)$ is accepted, it can be concluded that the alternative hypothesis $\left(\mathrm{H}_{1}\right)$ is not supported. This means that there is no significant difference in financial performance in the form of The effectiveness ratio of Locally-generated revenue is used to measure the effectiveness in realizing the revenue of the City government and is the level of achievement of the implementation of an activity or achievement achieved by the Bandar Lampung City Government. The results showed that the level of effectiveness of the Bandar Lampung City Government Locally-generated revenue in period II had decreased compared to a period I, the difference in decline was not significant to the difference in financial performance between period I and period II. The decrease in effectiveness in period II shows that the Bandar Lampung City Government has not been able to increase the realization of regional original revenues significantly. The revenue realization is below the amount budgeted by the Bandar Lampung City Government in the Regional Budget.

Based on the results of the study, it was found that the ratio of the effectiveness of the Locally-generated revenue did not differ significantly between the period I and period II. The results of this study are supported by Batafor, (2011) who examines the evaluation of financial performance in Lembata- East Nusa Tenggara and states that there is no significant difference in the period of local government leadership. Besides, Dwirandra, (2008) also said the same thing related to the financial performance in the Bali province, the regional financial performance was categorized as quite effective, effective, and very effective. The results of this study are following the findings of an audit conducted by the Audit Board of the Republic of Indonesia on the examination of the Bandar Lampung Regional Government Financial Report, examinations with specific objectives, and performance checks in the period of the 2006 FY. 2015. Furthermore, the results of performance checks on the management of Building Construction License and Nuisance permit retribution permits, which are one of the sources of Locallygenerated revenue in the Bandar Lampung City Government from 2013 to Semester I, 2014 concluded that the management was less effective. Furthermore, the Report of audit findings: audit reports issued by the National Audit Board of Bandar Lampung City, Regional Government Financial Reports 2015 revealed that the findings in the form of Locally-generated revenue administration in Bandar Lampung City had not been carried out optimally.

The efficiency ratio is intended to assess the achievement of the implementation of an activity achieved by the Bandar Lampung City Government as measured by comparing the expenditure realization with the previously determined expenditure budget. The results showed that there was no significant difference in the efficiency ratio between period I and period II. The results also showed that the level of financial management efficiency of the Bandar Lampung City Government in the I and II periods was in the inefficient category. The results of this study indicate that the Bandar Lampung City Government in the period I and period II tended to realize almost all of the stipulated budget, in other words, the Bandar Lampung Municipal Government tended to use all of the existing budgets. Besides, the Bandar Lampung City Government also tends always to want to optimize the budget that has been allocated in the Regional Revenue and Expenditure Budget. This research is also supported by Petrus, (2001) who examined the evaluation of the regional income and expenditure budget of Sikka Regency, East Nusa Tenggara Province from 1993-1998, using Ende and Manggarai districts as comparisons. The results showed that the average level of efficiency in the management of the Regional Revenue and Expenditure Budget of Sikka Regency, Ende Regency, and Manggarai Regency was categorized as inefficient, as evidenced by the efficiency ratio of the three districts ranging from 95.94-97.39 percent. The results of this study are following the Audit Board of the Republic of Indonesia audit findings contained in the Inspection Report of Regional Government Financial Reports examination of Bandar Lampung City, examination with specific objectives, and performance inspection in 2006 until 2015. These findings include the realization of capital expenditures on the road and building construction, which are not following the contract which results in an overpayment, the realization of improper motor vehicle tax payments, and evidence of accountability for employee travel that is incorrect.

Appropriateness/Indirect Expenditure Spending Ratio describes the Bandar Lampung City Government in prioritizing the allocation of funds to apparatus expenditure optimally so that it's utilized can be felt 
directly by all apparatuses. The results of this study indicate that the harmonization level of Apparatus Shopping/Indirect Expenditures of Bandar Lampung City Government in period II has decreased compared to the harmonization level of Apparatus Expenditures/Indirect Expenditures in a period I, but the difference in the decrease is not significant to the difference in financial performance between period I and period II. The results showed that the level of Apparatus Shopping/Indirect Expenditures of the Bandar Lampung City Government both in the period I and period II was in the quite harmonious category. Although in the second period, the harmony level of Apparatus/Indirect Expenditures of Bandar Lampung City Government increased from period I of 50.04\% to 51.87\% in period II.

The increase in the level of appropriateness of Apparatus / Indirect Expenditures of Bandar Lampung City Government in period II was caused by the low realization of Apparatus Expenditures/Indirect Expenditures compared to its budget so that it was far lower than the expenditure budget. The Bandar Lampung city government from the beginning has committed to working to improve the welfare of the community, one of which is by increasing apparatus spending. The increase in the allocation of apparatus service expenditure funds is insignificant compared to the distribution of funds in direct expenditure posts, the benefits of which are more directly felt by the community. Batafor, (2011), examined the evaluation of the financial performance of the Government of the District of Lembata East Nusa Tenggara Province, which stated that there was no significant difference in the apparatus expenditure harmony between several periods of government. During the years 2002-2009, the harmony level of Apparatus/Indirect Spending was in the category of quite harmonious.

Public Service Expense/Direct Spending Ratio describes the Bandar Lampung City Government in prioritizing the allocation of funds to the optimal public service expenditure so that its utilization can be felt directly by the entire community. The results of this study indicate that the level of harmony of public service expenditure / direct expenditure of Bandar Lampung City Government in period II has decreased compared to the level of balance of public service expenditure/direct expenditure in a period I, but the difference in the increase is not significant to the difference in financial performance between period I and period II. The results also showed that the level of Public Service Expenditures/Direct Expenditures of the Bandar Lampung City Government in the period I was in the quite harmonious category, while in period II it was in the less harmonious category. In period II, Public Service Expenditures/Direct Expenditures of Bandar Lampung City Government decreased from period I of $45.50 \%$ to $39.54 \%$ in period II.

The decrease in the level of harmony of public service expenditure / direct expenditure of the Bandar Lampung city government in period II was due to the low realization of overall regional spending, such as spending on public services, which was insignificant. According to Batafor (2011), this happens because some community groups can only feel the reality that occurs when the government increases the allocation of funds for public service expenditure. The results of this study are following the study Batafor (2011), which examines the evaluation of the financial performance of the Government of the District of Lembata - East Nusa Tenggara Province, which states that there is no significant difference in the harmony of spending between several periods of government. During the years 2002-2009, the harmony level of spending was in the pretty harmonious predicate.

The financial growth ratio illustrates the regional government in the relevant fiscal year or during the budget period, the Regional Revenue and Expenditure Budget Financial Performance experienced positive or negative growth. Of course, it is expected that positive revenue growth and trends will increase. Conversely, if there is a negative growth, then it will indicate a decline in the financial performance of regional income. The results of this study indicate that the level of financial growth of the Bandar Lampung City Government in period II has decreased compared to the level of financial growth in the period I, but the difference in decline is not significant to the difference in financial performance between period I and period II. The decline in the level of financial growth of the Bandar Lampung City Government in period II was due to the suboptimal realization of revenue each year. The financial growth ratio of the Bandar Lampung City Government shows the ability of management in the past. So when there is a decrease in financial growth it can be interpreted that financial management in the past was low. 
Halim, (2017) states that the higher the growth ratio the value of Total Regional Revenue, Locallygenerated revenue, and Capital Expenditures followed by lower Operational Expenditures, the growth is positive. This means that the area concerned has been able to maintain and increase its growth from one period to the next. But this has not yet fully happened in the Bandar Lampung City government. The Bandar Lampung City Government's financial growth ratio shows a decline from the period I to period II but is still in a positive ratio which means that an increase in total regional income every year is followed by higher expenditure realization, so financial growth, although positive, is not too significant. This means that the Bandar Lampung City Government has not been able to properly maintain and increase its growth from one period to the next, which can be seen from the declining growth trend, especially in period II.

The results of this study are following the Audit Board of the Republic of Indonesia audit report for the examination of the Regional Government Financial Reports of Bandar Lampung City in the period of the 2006 FY, FY 2015. The findings include financial management in FY 2014 and FY 2015 not paying attention to regional financial capacity where the presentation of surplus value in the Report on-budget results (Statement of Budget Realization): the main document in the accountability cycle of the budget cycle does not reflect the actual value of the surplus because it still must pay debts in the next fiscal year. Presentation of a surplus-value of Rp36,528,741,699.31 presented at the 2014 Report on-budget results (Statement of Budget Realization): the main document in the accountability cycle of the budget cycle does not reflect the actual surplus because the Bandar Lampung City Government still must pay debts on the next FY, namely 2015 FY of Rp143,303,884,462.38 so that it experiences a deficit of Rp.106,775,142,763.07. This condition still occurred in FY 2015 where the surplus value was presented at Rp86,120,811,358.11 and Unspent funds at end of the fiscal year, carried forward to the ensuing year of Rp24,563,686,310.24, but in real terms, the Bandar Lampung City Government experienced a deficit of Rp307,021,967,719.77. So that the presentation of the surplus-value in the 2015 Report on-budget results (Statement of Budget Realization): the main document in the accountability cycle of the budget cycle does not reflect the actual condition of the surplus. This condition can be said that regional financial capacity as a consideration of financial management has not been the main concern. This is indicated by the value of the real deficit increasing from FY 2014 to FY 2015 amounting to 5.38\% (Rp.106,775,142,763.07 / Rp1,985,273,081,931.26 x 100\%) to 13.20\% (Rp307. 021,967,719,77 / $\mathrm{Rp} 2,325,136,392,212.82 \times 100 \%)$. The regional government to make efforts to increase the fiscal capacity of the region by calculating the Original Local Government Revenue through better policies and the expansion of regional tax collection spaces that are comprehensive and always in favor of the society. To increase regional financial independence, regional governments must be able to explore regional income potentials that have not been touched and conduct effective supervision of tax collection and levies as a major component of Original Local Government Revenue (Arslan, Tschirley, \& Egger, 2020; Karimah et al., 2020; Yasin, 2020).

\section{Conclusion}

Based on the results of data analysis and discussion that has been stated, it can be concluded that there is no significant difference in average financial performance in the form of effectiveness ratio, efficiency ratio, the ratio of expenditure harmony, and financial growth ratio of Bandar Lampung City government in the period I and period II. This shows that the Bandar Lampung City Government has not been able to significantly improve its financial performance. This is because the management of regional finances carried out in period II has not been carried out properly. In managing regional finances, the city government of Bandar Lampung has not implemented financial management in a transparent, honest, democratic, effective, efficient and accountable manner. No matter how big the potential of a region is, it will not be optimally utilized if the Regent / Mayor does not know how to manage it.

\section{Limitation and further research \\ Limitation}

The limitations in this study are:

1. This Research only focuses on the financial performance of Bandar Lampung City Government. 
2. Time limitation, this research was carried out in only two mayor periods (2006 - 2010 VS $2011-2015)$.

Further research

Based on the limitation of this research, the author offers several suggestion for future researchers as follows:

1. Future research should look for other variables that might influence on local government performance.

2. In order for the research to be widely used, the subject of further research should not only from Bandar Lampung City Government, but from other City Government as well.

3. The research time must be longer so that the data obtained is better.

\section{Acknowledgment}

We would like to thank all the postgraduate lecturers at the Faculty of Economics and Business Lampung University for their helpful comments and suggestions. Comments and suggestions from reviewers and editors significantly improve our paper. We take full responsibility for any errors contained in this paper.

\section{References}

Abdul, H., \& Syam, K. (2012). Akuntansi Sektor Publik. Salemba Empat.

Abdullah, S. (2017). Akuntansi Sektor Publik Akuntansi Keuangan Daerah.

Arifin, J. (2017). SPSS 24 untuk Penelitian dan Skripsi. Elex Media Komputindo.

Arslan, A., Tschirley, D. E., \& Egger, E.-M. (2020). Rural youth welfare along the rural-urban gradient: An empirical analysis across the developing world. The Journal of Development Studies, 1-25.

Barr, N. (2020). Economics of the welfare state. Oxford University Press, USA.

Batafor, G. G. (2011). Evaluasi kinerja keuangan dan tingkat kesejahteraan masyarakat Kabupaten Lembata-Provinsi NTT. Program PascaSarjana: Universitas Udayana.

Bjurstrøm, K. H. (2020). Principal-agent or principal-steward: how ministry-agency relations condition the impact of performance management in the steering of government agencies. Public Performance \& Management Review, 1-25.

Boberg-Fazlic, N., \& Sharp, P. (2013). North and south: social mobility and welfare spending in preindustrial England. European Historical Economics Society (EHES) Working Paper, 37.

Dwirandra, A. (2008). Efektivitas dan kemandirian keuangan daerah otonom kabupaten/kota di Provinsi Bali tahun 2002-2006. Jurnal.

Eisenhardt, K. M. (1989). Agency theory: An assessment and review. Academy of Management Review, 14(1), 57-74.

Halim, A. (2017). Kajian tentang keuangan daerah pemerintah kota Malang. E-Repository Dosen Universitas Gajayana Malang.

Halim, A., \& Kusufi, M. S. (2012a). Akuntansi sektor publik. Jakarta: Salemba Empat.

Halim, A., \& Kusufi, M. S. (2012b). Teori konsep, dan aplikasi akuntansi sektor publik (Jilid 1). Jakarta Selatan: Salemba Empat.

Halim, A., \& Kusufi, M. S. (2014a). Akuntansi sektor publik: teori, konsep, dan aplikasi (Edisi 2.). Jakarta: Salemba Empat.

Halim, A., \& Kusufi, M. S. (2014b). Teori, konsep, dan aplikasi akuntansi sektor publik. Jakarta: Salemba Empat.

Jensen, M. C., \& Meckling, and W. H. (1976). Theory of the firm: managerial behavior, agency costs and ownership structure.

Jensen, M. C., \& Meckling, W. H. (1979a). Rights and production functions: an application to labormanaged firms and codetermination. Journal of Business, 469-506.

Jensen, M. C., \& Meckling, W. H. (1979b). Theory of the firm: M\#managerial behavior, agency costs, and ownership structure. In Economics social institutions (pp. 163-231). Springer.

Karimah, N. N., Sarwani, S., \& Adriani, A. (2020). Analysis of regional government financial performance and impact on welfare society. AKUNTABEL, 17(1), 98-108.

Kuncoro, H. (2004). Pengaruh transfer antar pemerintah pada kinerja fiskal pemerintah daerah kota dan 
kabupaten di Indonesia. Economic Journal of Emerging Markets, 9(1).

Ma'ruf, A., \& Wihastuti, L. (2008). Pertumbuhan ekonomi Indonesia: determinan dan prospeknya. Jurnal Ekonomi \& Studi Pembangunan, 9(1), 44-55.

Mahmudi. (2007). Analisis laporan keuangan pemerintah daerah: panduan bagi eksekutif, DPRD, dan masyarakat dalam pengambilan keputusan ekonomi, sosial, dan politik. UPP STIM YKPN.

Mankiw, N. G. (2014). Principles of economics. Cengage Learning.

Mogues, T., \& Benin, S. (2012). Do external grants to district governments discourage own revenue generation? A look at local public finance dynamics in Ghana. World Development, 40(5), 10541067.

Nirwana, E., Taufik, T., \& Ratnawati, V. (2014). Evaluasi kinerja keuangan dan tingkat kesejahteraan masyarakat pada Pemerintahan Kabupaten Bengkalis. Sorot, 9(1), 1-16.

Oates, W. E. (1993). Fiscal decentralization and economic development. National Tax Journal, 46(2), 237-243.

PETRUS, D. S. (2001). Evaluasi anggaran pendapatan dan belanja daerah Kabupaten Sikka 1995/1996-2000. Universitas Gadjah Mada.

Pigou, A. C. (2013). The economics of welfare. Palgrave Macmillan.

Pramesti, G., \& Si, M. (2015). Kupas tuntas data penelitian dengan SPSS 22. Elex Media Komputindo.

Purnomo, R. A. (2016). Analisis statistik ekonomi dan bisnis dengan SPSS. CV. WADE GROUP bekerjasama dengan UNMUH Ponorogo Press.

Rahmawati, R. A., \& Mahmudi, A. (2016). Faktor-faktor yang mempengaruhi transparansi pelaporan keuangan pemerintah daerah. Accounting Analysis Journal, 5(2), 122-130.

Sochib, S. (2016). Pengaruh capital adequacy ratio, debt to equity ratio, rasio biaya operasional pendapatan operasional, dan loan to deposit ratio terhadap kinerja keuangan bank umum swasta nasional yang go public di Bursa Efek Indonesia. Jurnal Penelitian Ilmu Ekonomi WIGA, 6(1), 114.

Suharto, E. (2005). Membangun Masyarakat Memberdayakan Rakyat Kajian Strategis Pembangunan Kesejahteraan Sosial dan Pekerjaan Sosial. PT Refika Aditama.

Sularso, H., \& Restianto, Y. E. (2012). Pengaruh kinerja keuangan terhadap alokasi belanja modal dan pertumbuhan ekonomi kabupaten/kota di Jawa Tengah. Media Riset Akuntansi, 1(2).

UNDP (United Nations Development Program). (2010). The real wealth of nations: Pathways to human development.

Utama, S. J. A. (2015). Pengaruh pdrb, belanja modal dan kemiskinan terhadap indeks pembangunan manusia (studi kasus: eks karesidenan besuki.

Wahyudi, S. T. (2017). Statistika ekonomi konsep, teori dan penerapan. Universitas Brawijaya Press.

Whitney, M. (2013). Fate of the states: the new geography of American prosperity. Penguin.

Yasin, M. (2020). Analysis of regional original revenues and routine expenditures on regional financial performance in East Java Regencies and Cities. Jurnal Mantik, 3(4), 64-69.

Zafra-Gómez, J. L., López-Hernández, A. M., \& Hernández-Bastida, A. (2009). Evaluating financial performance in local government: maximizing the benchmarking value. International Review of Administrative Sciences, 75(1), 151-167. 